\section{Biosynthesis of Triiodothyronine Sulphate by Beef Thyroid in vitro}

IT is well recognized that the thyroid gland contains the $\mathrm{L}$-amino acids, triiodothyronine $\left(\mathrm{T}_{3}\right)$, thyroxine $\left(\mathrm{T}_{4}\right)$, monoiodotyrosine (MIT), diiodotyrosine (DIT) and iodinated thyronines which are free (unconjugated) but are bound to thyroglobulin. The release of these iodinated amino-acids occurs after digestion by protein-hydrolysing enzymes or chemicals, but the possibility of observing any $\mathrm{T}_{\mathbf{s}}$ and/or $\mathrm{T}_{\mathbf{q}}$ sulphate conjugates per se in thyroid tissues seoms unlikely since hydrolytic procedures would have precluded their isolation.

The conversion of triiodothyronine $\left(\mathrm{T}_{3}\right)$ to triiodothyronine sulphate $\left(\mathrm{T}_{8} \mathrm{~S}\right)$ presumably occurs in the liver ${ }^{1}$ since Roche, Michel, Closon, and Michel demonstrated the presence of $T_{8} S$ in the bile and plasma of thyroidectomized rats. However, the well-established evidence for extrahepatic mammalian steroid sulphokinase activity in endocrine glands such as adrenal ${ }^{2,3}$ and ovary ${ }^{4}$ stimulated an investigation of $T_{3}$ sulphokinase activity in mammalian thyroid tissues.

Fresh beef thyroid glands were homogenized at $4^{\circ} \mathrm{C}$ in $0.25 \mathrm{M}$ sucrose, containing $0.05 \mathrm{M}$ tris (tris hydroxymethyl aminomethane) and 0.002 M EDTA (ethylenediaminetetraacetate) at $p \mathbf{H} 7 \cdot 5$. The crude homogenate was filtered through cheese cloth and fractionated by ultracentrifugation according to the method of Fischer, Schultz and Oliner ${ }^{5}$. The fractions I-IV (ste Table 1) were stored frozen until assayed.

The assay mixture included $100 \mu \mathrm{mol}$ imidazole $\mathrm{HCl}$ buffer, $p \mathrm{H} 7 \cdot 0,12.5 \mu \mathrm{mol} \mathrm{MgCl}_{2}, 1.0 \mu \mathrm{mol}$ triiodothyronine (Sigma), $10 \mu \mathrm{mol}$ cysteine (neutralized), $10 \mu \mathrm{mol}$ $\mathrm{K}_{4} \mathrm{ATP}, 10 \mu \mathrm{mol} \mathrm{K}_{2} \mathrm{SO}_{4}, 0.2 \mathrm{ml}$. yeast sulphate-activating enzyme $^{6}$ and $0.2 \mathrm{ml}$. thyroid sulphokinase fraction in a final volume of $1.0 \mathrm{ml}$. Incubation was carried out for 35 min in air at $37^{\circ} \mathrm{C}$ in the Dubnoff metabolic shaker.

Control flasks included zero time, and mixtures incubated without various components including enzymes. The $T_{3} S$ was determined by the methylene blue method of Nose and Lipmann?. A standard curve was prepared by the use of the ammonium $T_{3} S$ which was synthesized by the method of Fieser ${ }^{8}$. Protein was measured spectrophotometrically by the method of Gornall and colleagues ${ }^{9}$.

Table 1. $\mathrm{T}_{\mathbf{8}}$ SUlphokinase ACTIVITY OF BEEF THYROID Fractional ultracentrifugation $\quad \mathrm{m} \mu \mathrm{mol} \mathrm{T}_{3} \mathrm{~S}$ formed per $\mathrm{mg}$ $\begin{array}{ll}\text { Fraction I } & \text { Filtered crude homogenate } \\ \text { Fraction II } & 700 \mathrm{~g} \text { for } 10 \text { min supernatant } \\ \text { Fraction III } & 12,000 \mathrm{~g} \text { for } 10 \mathrm{~min} \text { supernatant }\end{array}$ Fraction IV $105,000 \mathrm{~g}$ for $60 \mathrm{~min}$ supernatant

of protein
92
161
182
216

The results of a typical incubation are listed in Table 1. The identification of ammonium ${ }^{T} \mathrm{~T}_{\mathrm{g}} \mathrm{S}$ sulphate in the incubation mixture followed the addition of concentrated ammonium hydroxide and extraction with $n$-butyl alcohol. Identical mobilities of the unknown and standard were observed after descending paper chromatography in the $n$-butyl alcohol, $2 \mathrm{~N}, \mathrm{NH}_{4} \mathrm{OH}$ system and paper electrophoresis in the $\left(\mathrm{NH}_{4}\right)_{2} \mathrm{CO}_{3}, 0.05 \mathrm{M}, p \mathrm{H} 9$ according to the methods of Roche et al. ${ }^{1}$. The $\mathbf{T}_{3} \mathrm{~S}$ was located by positive ninhydrin stain and Schneider, Lewbart modification of the rhodizonic acid test for sulphate ions ${ }^{10}$.

The data indicate that $T_{3}$ sulphokinase activity is present in beef thyroid tissue and that the highest enzymatic activity is in the microsome-free supernatant. It is of interest that sulphokinase activity is also highest in the hepatic and adrenal microsome-free fraction, that is $105,000 \mathrm{~g}$ supernatant. The thyroid $\mathrm{T}_{\mathbf{3}}$ sulphokinase activity remained constant for at least 3 months despite frequent freezing and thawing.

Preliminary studies suggest that beef thyroid microsomefree supernatant synthesizes $T_{4}$ sulphate $\left(T_{4} S\right)$ in the same order of magnitude as $\mathrm{T}_{3} \mathrm{~S}(210 \mathrm{~m} u \mathrm{~mol}$ per mg of protein per $35 \mathrm{~min}$ ). Additional studies are in progress to purify $\mathrm{T}_{3}$ and $\mathrm{T}_{4}$ sulphokinase( $\mathrm{s}$ ) and to study the enzyme kinetics involved.
I thank Drs. Arthur Schultz and Leo Oliner for supplying the initial frozen beef thyroid preparations. This work was supported by grant $A-4783$, National Institutes of Health, Division of Arthritis and Metabolism, Bethesda, Maryland.

George L. COHN

Department of Internal Medicine,

Yale University School of Medicine,

New Haven 11, Connecticut.

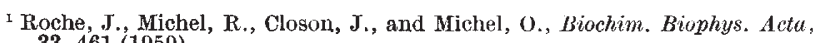
33, 461 (1959).

"Wallace, E., and Lieberman, S., J. Clin. Endocrinol. Metab., 23, 90 (1963).

${ }^{3}$ Cohn, G. L., Mulrow, P. J., and Dunne, V. C., J. Clin. Endocrinol. Metab. 23, 671 (1963).

${ }^{4}$ Wallace, E., and Silberman, N., J. Biol. Chem., 239, 2809 (1964).

'Fischer, A. G., Schultz, A. R., and Oliner, L., Biochem. Biophys. Res. Comm., $14,39(1964)$.

${ }^{6}$ Robbins, P. W., and Lipmann, F., J. Amer. Chem. Soc., 78, 6409 (1956).

7 Nose, Y., and Lipmann, F., J. Biol. Chem., 233, 1348 (1958).

${ }^{8}$ Fieser, L. F., J. Amer. Chem. Soc., 70, 3232 (1948).

' Gornall, A. G., Bardawill, C. J., and David, M. M., J. Biol. Chem., 17'7, 751 (1949).

${ }^{10}$ Schneider, J. J., and Lenbart, M. L., J. Biol. Chem.,222, 787 (1956).

\section{PHYSIOLOGY}

\section{Effect of 'Furosemid' on Chloride and Water Excretion in Single Nephrons of the Kidney of the Rat}

IT has been shown by Muschaweck and Hajdú ${ }^{1}$ that in the dog, at doses of $10 \mathrm{mg} / \mathrm{kg}$ body-wt. and more, 'Furosemid' (4-chloro- $N$ (2-furylmethyl)-5-sulphamoyl-arthranylic acid) markedly increases the excretion of water, sodium and chloride. These authors also showed that the increase in chloride excretion was proportionally greater than that of sodium and water. On the other hand, Karger and $\mathrm{Nagel}^{2}$ found a reduced permeability to anions, especially chloride, in the frog skin after addition of 'Furosemid' at concentrations of $25-500 \mathrm{mg} / \mathrm{l}$. to the bathing solution, as evidenced by increased transmembrane potential differences without change in the short circuit current. Deetjen ${ }^{3}$ obtained proximal and distal tubular fluid samples in rats with an intravenous infusion of $2 \mathrm{mg} / \mathrm{kg} / \mathrm{min}$ and observed significantly decreased proximal fluid/plasma $(\mathbf{F} / \mathbf{P})$ inulin ratios, as well as ratios below 2 in the distal tubule, concluding that 'Furosemid' depresses water and salt re-absorption in the proximal tubule and ascending limb of Henle's loop. Clearance studies by Suki, Rector and Seldin ${ }^{4}$ also indicated that 'Furosemid' might have an effect on the activity of the re-absorptive mechanisms of the proximal tubule and the ascending limb of Henle's loop.

Having this evidence in mind, we decided to investigate the fate of chloride along the nephron of the rat kidney, using micropuncture methods as described by Windhager and Giebisch ${ }^{5}$. Extreme care was taken in the collection of distal tubular samples, using rather long oil blocks (at loast four times the tubular diameter), and checking the direction of flow by subsequent microdissection. Chloride and inulin were measured simultaneously, the first by the second coulometric method of Ramsay et al..$^{6}$, the second by a modification of the microanthrone method of Hilger et al. ?. 'Furosemid' was infused in saline $(0.05 \mathrm{ml} . / \mathrm{min})$ at a rate of 0.8 to $1 \mathrm{mg} / \mathrm{kg} / \mathrm{min}$, sufficient to produce a marked diuresis. In parallel experiments the same measurements were done in control rats receiving saline infusion $(0.05 \mathrm{ml} . / \mathrm{min})$ and in animals receiving a 4 per cent sodium chloride infusion at a rate of $0.1 \mathrm{ml} . / \mathrm{min}$.

Mean glomerular filtration rate $(\mathrm{GFR})$ was $3.21 \mathrm{ml} . / \mathrm{kg} /$ min in the 'Furosemid' group, 4.22 in the control group, and 5.77 in the 4 per cent sodium chloride group. Mean urinary $p H$ was $6 \cdot 32$ (range $5 \cdot 95-6 \cdot 71$ ) in the control group, $6 \cdot 50(5 \cdot 99-6 \cdot 83)$ in the 4 per cent sodium chloride infused, and $5 \cdot 26(4 \cdot 76-5 \cdot 82)$ in the 'Furosemid' group.

In Table $1 a$ mean chloride $\mathrm{F} / \mathrm{P}$ ratios in proximal and distal tubules, as well as chloride $\mathrm{U} / \mathrm{P}$ ratios, are shown 